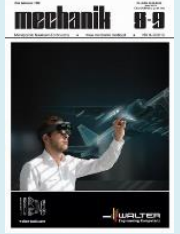

Authors: Marcin Żółkoś, Witold Habrat, Janusz Świder, Elżbieta Socha

Title of article: „Analiza oddziaływania zużycia ściernicy z korundu monokrystalicznego na siłę szlifowania i chropowatość powierzchni w procesie szlifowania obwodowego stali 100Cr6" ("Analysis of influence of the mono-crystalline corundum grinding wheel wear on grinding forces and roughness parameters in peripheral surface grinding of $100 \mathrm{Cr} 6$ steel")

Mechanik, Vol. 91, No. 8-9 (2018): pages 702-704

DOI: https://doi.org/10.17814/mechanik.2018.8-9.110

\title{
Analysis of influence of the mono-crystalline corundum grinding wheel wear on grinding forces and roughness parameters in peripheral surface grinding of $100 \mathrm{Cr} 6$ steel
}

\author{
Analiza oddziaływania zużycia ściernicy z korundu monokrystalicznego \\ na siłę szlifowania i chropowatość powierzchni \\ w procesie szlifowania obwodowego stali $100 \mathrm{Cr} 6$
}

\author{
MARCIN ŻÓŁKOŚ \\ WITOLD HABRAT \\ JANUSZ ŚWIDER \\ ELŻBIETA SOCHA *
}

The paper presents the experimental study conditions and results of M3X60K5VE01-35 monocorundum with vitrified bond grinding wheel wear in $100 \mathrm{Cr} 6$ steel peripheral grinding process. The effect of grinding wheel wear on the values of grinding force components as well as surface roughness parameters was analyzed. The grinding wheel wear was determined by profile measurement of the active grinding wheel surface using an inductive sensor. It was shown that the increase in the normal component of the grinding force during the process can be an acceptable criterion for wear of the grinding wheel due to the quasi-linear changes over time. KEYWORDS: peripheral surface grinding, $100 \mathrm{Cr} 6$, wear, M3X60K5VE01-35

In the grinding process an important role is played by the phenomenon of grinding wheel wear, which affects process efficiency, grinding force component values and surface quality after machining $[1,2]$. It is important, therefore, that the grinding wheel does not lose, during the entire lifetime, macro-geometry obtained during the dressing process. This ensures obtaining the intended shape of the workpiece and translates into less frequent restoration of the original profile of the grinding wheel active surface (GWAS). This is inextricably linked to an increase in the efficiency of the grinding process by reducing the ratio of preparation times to machining times.

The course of grinding wheel wear depends on the abrasive grain used, the composition of the bonding material and the method of production [1, 2]. The striving to increase efficiency by reducing grinding wheel wear has various forms, among others developing new varieties of abrasives, developing and modifying existing materials or using different blends of abrasive grains.

\footnotetext{
* Mgr inż. Marcin Żółkoś (markos@prz.edu.pl), dr inż. Witold Habrat (witekhab@prz.edu.pl) - Wydział Budowy Maszyn i Lotnictwa Politechniki Rzeszowskiej; dr inż. Janusz Świder (swider@cerel.pl) - Instytut Energetyki Oddział Ceramiki CEREL; dr inż. Elżbieta Socha (elzbieta. socha@andre.com.pl) - Andre Abrasive Articles
}

Vitrified binders are one of the most commonly used bonding materials for the production of grinding wheels. This state of affairs is due to properties such as high temperature resistance, inelasticity and resistance to the influence of coolant. Due to their high strength, they allow for the creation of grinding wheels with different porosity, and also enable the widest scale of hardness [1, 3]. In addition, they are hard and do not soften under the influence of high temperature, thus providing grinding wheels with a good ability to maintain their shape. For this reason, vitrified bonded grinding wheelsare used for precision grinding of surfaces, shafts, holes and profiles.

The article analyzes the impact of mono-corundum grinding wheel wear with vitrified bond on grinding force and surface roughness in $100 \mathrm{Cr} 6$ steel peripheral grinding process. This analysis was based on measurements of the grinding wheel active surface profiles, grinding force components and surface roughness.

\section{Experimental study conditions}

Experimental tests of the surface peripheral grinding process were carried out in the Department of Manufacturing Techniques and Automation laboratory at the research stand (fig. 1), of which the basic part is the FS 640 surface grinding machine from Geibel \& Hotz $\mathrm{GmbH}$. The stand has been equipped with Kistler type 9121 piezoelectric dynamometer, that allows the measurement of grinding force components. A MarSurf PS 10 profilometer from Mahr was used to measure the surface roughness. Measurements of the grinding wheel active surface were made using the TESA GT21 contact inductive sensor.

The machined material was $100 \mathrm{Cr} 6$ steel, through hardened and tempered to 58 HRC hardness. The Andre Abrasive Articles grinding wheel (type 7), was used for the examination, with a two-sided cylindrical recess $A$ (according to the company's catalog [4]). The tested wheel with the designation M3X60K5VE01-35 has medium sized abrasive grains made of monocrystalline corundum, with a $30 \%$ share of microcrystalline electro-corundum, bonded with vitrified binder. 


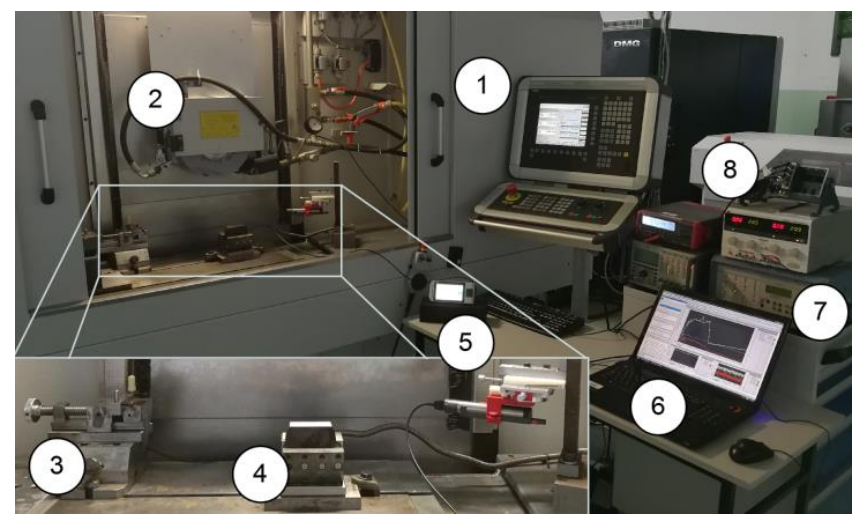

Fig. 1. View of the test bench: 1 - FS 640 Z surface grinder; 2 - reference grinding wheel; 3 - diamond dresser and contact inductive sensor; 4 - workpiece, mounted in a dynamometer 5 - MarSurf PS 10 profilometer in an adjustable holder; 6 - computer with LabVIEW SignalExpress software; 7 - Kistler 5019 A amplifier; 8- measuring cardNI 9215

\section{TABLE. Test conditions}

\begin{tabular}{|c|c|}
\hline Machine tool & $\mathrm{G}+\mathrm{H}$ FS $640 \mathrm{Z}$ \\
\hline Machining type & $\begin{array}{l}\text { surface peripheral up } \\
\text { grinding }\end{array}$ \\
\hline Machined material & steel 100Cr6, $58 \mathrm{HRC}$ \\
\hline Tested grinding wheel & $\begin{array}{c}\text { peripheral grinding } \\
\text { wheel } \\
\text { 7-300x50×76.2 } \\
\text { P100;F10;G10 } \\
\text { M3X60K5VE01-35 }\end{array}$ \\
\hline Average size of abrasive grain $F, \mu \mathrm{m}$ & 275 \\
\hline Number of machining passes & 1 \\
\hline Number of sparking passes & 3 \\
\hline Grinding length $I_{\mathrm{s}}, \mathrm{mm}$ & 50 \\
\hline Grinding width $a_{p}, \mathrm{~mm}$ & 30 \\
\hline Process cooling & flood \\
\hline Cutting fluid pressure $p, \mathrm{MPa}$ & 1 \\
\hline $\begin{array}{l}\text { Cutiing fluid volumetric flow rate } q \text {, } \\
\text { l/min }\end{array}$ & 22 \\
\hline Coolant & $5 \%$ synthetic emulsion \\
\hline Peripheral speed for grinding $v_{\mathrm{s}}, \mathrm{m} / \mathrm{s}$ & 30 \\
\hline Feed rate $v_{\mathrm{f}}, \mathrm{mm} / \mathrm{min}$ & 4000 \\
\hline Grinding depth $a_{e}, \mathrm{~mm}$ & 0.02 \\
\hline Peripheral speed for dressing $v_{d}, \mathrm{~m} / \mathrm{s}$ & 25 \\
\hline Dressing depth $a_{e d}, \mathrm{~mm}$ & 0.02 \\
\hline Number of passes for dressing & 3 \\
\hline Coverage rate when dressing $k_{d}$ & 6 \\
\hline
\end{tabular}

The tests were carried out in the surface peripheral up grinding setupwith a surface width of $30 \mathrm{~mm}$ and a length of $50 \mathrm{~mm}$.

Before the grinding wheel wear process, the grinding wheel was dressed with a single grain diamond dresser, and then in subsequent machining passes - material removal. One machining pass consisted of four component passes. In the first pass, the infeed and removal of most of the material followed, while the next three were sparking passes. Grinding was performed with fixed technological parameters whose values are presented in the table. During the machining, a high pressure cooling system was used, in which a coolant in the form of a $5 \%$ synthetic emulsion was fed into the grinding zone by means of a needle nozzle at a pressure of $1 \mathrm{MPa}$, which corresponded to a volumetric flow rate of $22 \mathrm{l} / \mathrm{min}[5,6]$.

Values of the grinding force components were recorded for each machining pass, whereas the surface roughness and the grinding wheel active surface measurements were made after the first pass (treated as reference values) and then - every 20 machining passes.

\section{Results of experimental research}

The main objective of the research was to determine the impact of grinding wheel wear from monocrystalline corundum on the component grinding forces and surface roughness in the $100 \mathrm{Cr} 6$ steel peripheral grinding process. As part of the research, the process of M3X60K5VE01-35 grinding wheel wear was evaluated. The assessment was carried out on the basis of surface roughness measurements and component values of the grinding force during wearing of the grinding wheel, determined by measuring the radial wear. The radial wear was determined on the basis of the grinding wheel active surface (GWAS) profile according to fig. 2. The course of changes of the measured output values was determined in time, referring to the number of grinding cycles. A total of 101 machining cycles were carried out, during which $3030 \mathrm{~mm} 3$ of the workpiece material was removed. The change of grinding wheel radial wear during 101 grinding cycles is shown in fig. 3 .

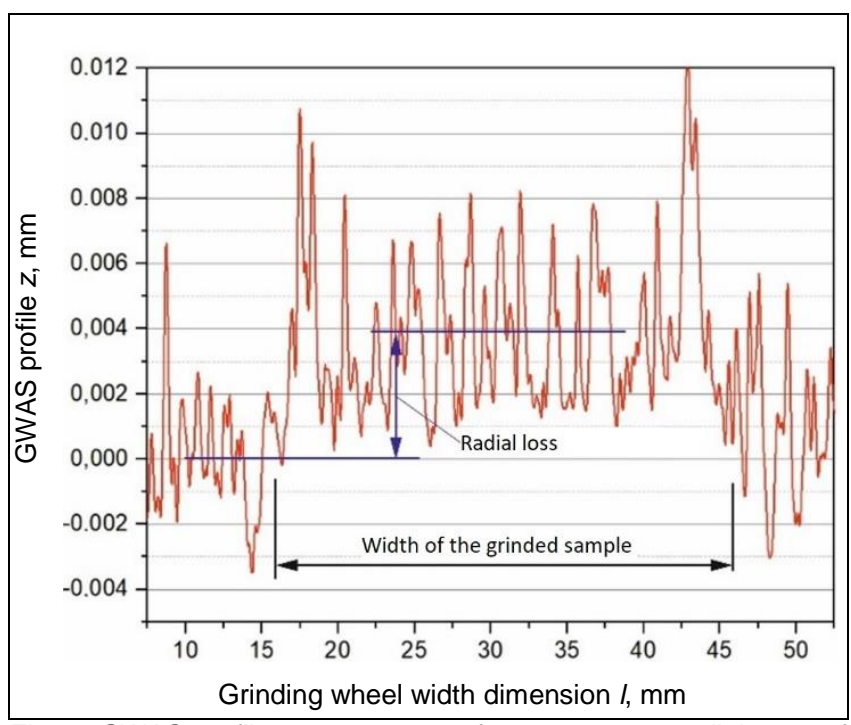

Fig. 2. GWAS profile measurement after 101 pass - radial wear of the grinding wheel $w=0.0038 \mathrm{~mm}$ is visible on the graph

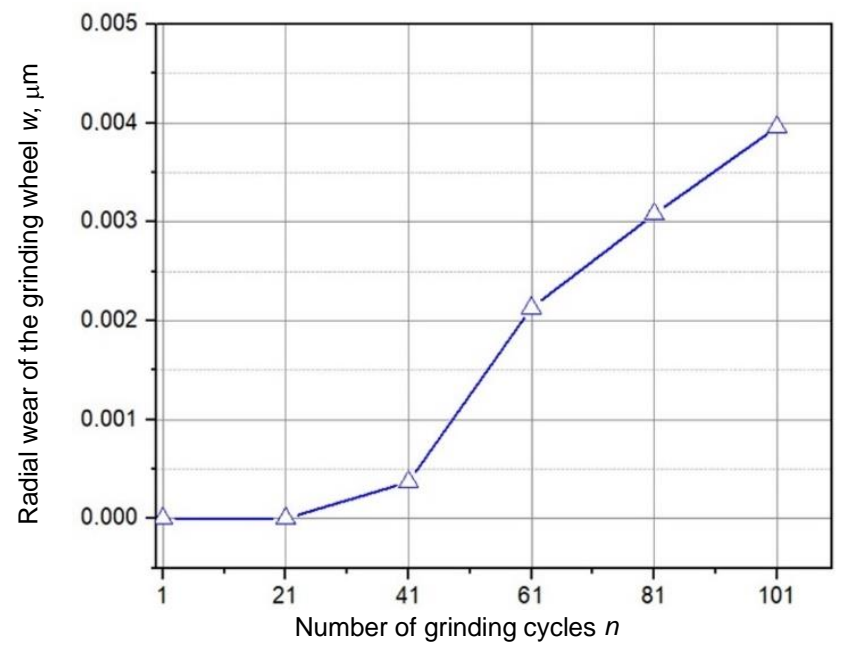

Fig. 3. Changes in the radial wear of the grinding wheel during the course of 101 grinding cycles

In the period up to the 41st grinding cycle, wear was characterized by a slight radial wear. After this cycle, there was a significant increase in the intensity of wear, which was probably related to the self-sharpening process by the chipping of abrasive grains. Analyzing the changes in the grinding force components, it can be seen that the increase in the normal component during the first 40 cycles was over $30 \%$ lower than for the next 40 cycles (fig. 4). Another relation was obtained for the tangential component - in this case, the increase for the next 40 cycles was $57 \%$ lower than in the initial phase of wear. The change in the 
mechanism of wear (occurring around the 41 st cycle) is manifested by a change in the ratio of the value of the grinding force normal component to the tangential component (fig. 5).

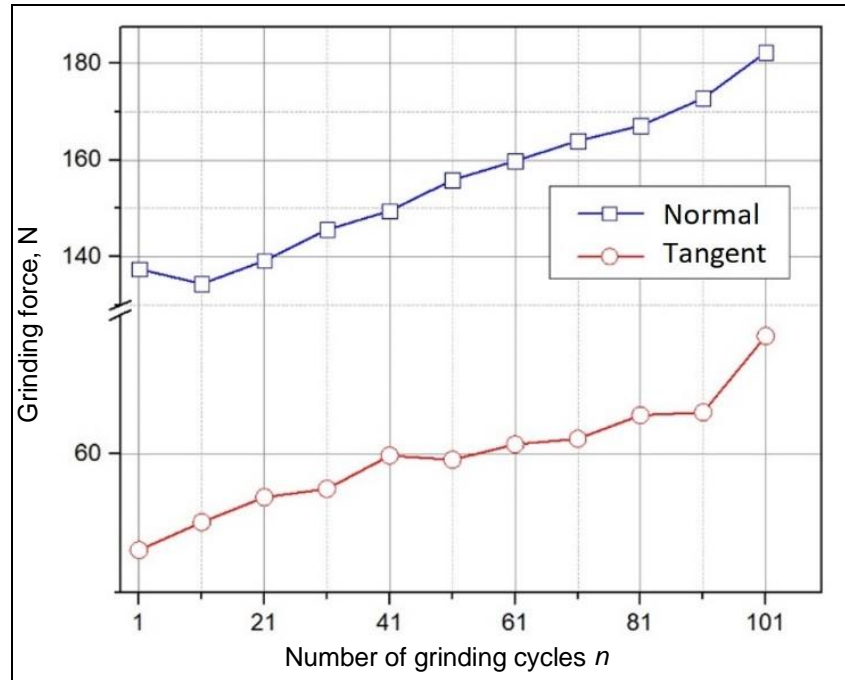

Fig. 4. Change in the normal and tangential force of the grinding force with determined process parameters $\left(v_{\mathrm{s}}=30 \mathrm{~m} / \mathrm{s}, v_{f}=4000\right.$ $\mathrm{mm} / \mathrm{min}, a_{e}=0.02 \mathrm{~mm}$ ) as a result of the grinding wheel wear during the 101 grinding cycles

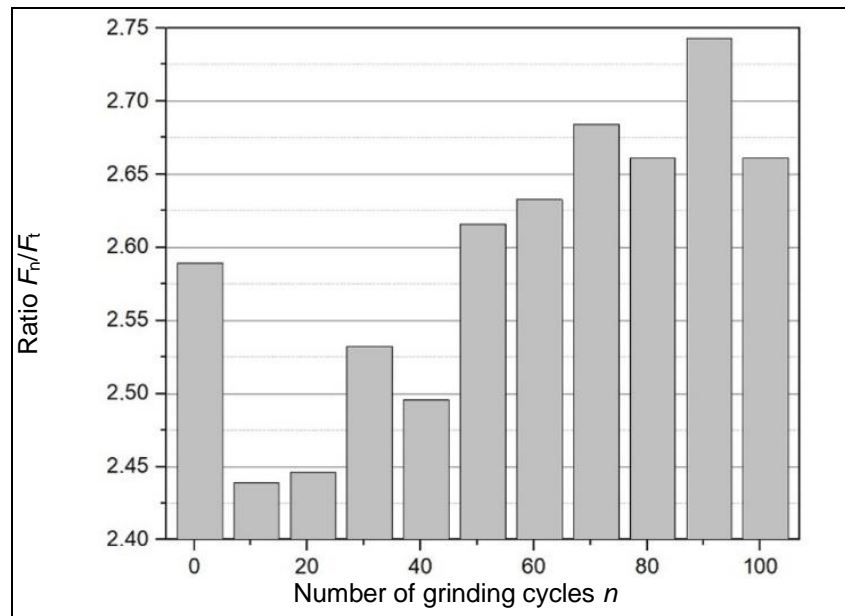

Fig. 5. Change in the ratio of the normal component $F_{\mathrm{n}}$ to the tangent component $F_{t}$ of the grinding force as a result of the grinding wheel wear during the 101 grinding cycles

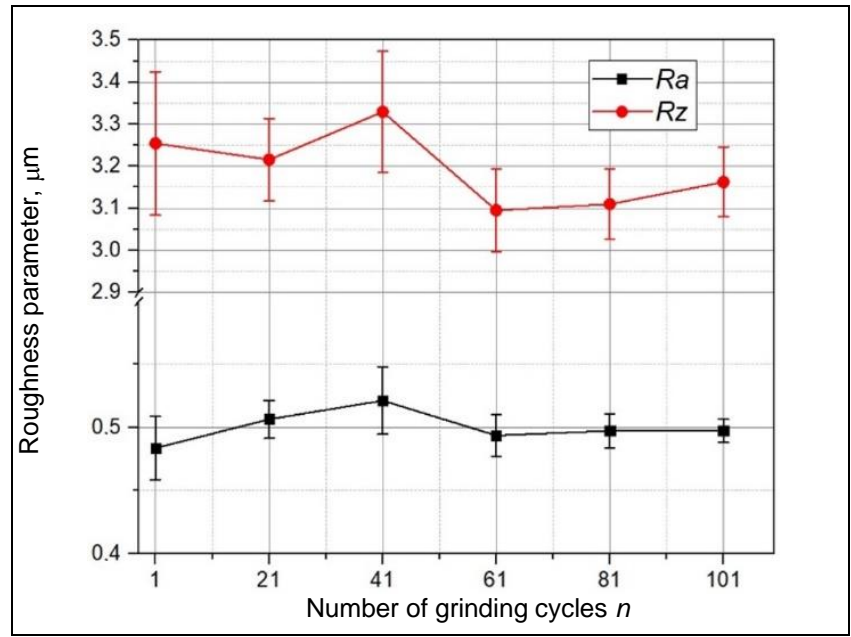

Fig. 6. Change of roughness parameters $R a$ and $R z$ as a result of wear of grinding wheel during the period of 101 grinding cycles

Changing the mechanism of wear - from the dulling of mono-corundum grains in the initial phase to chipping and opening of new cutting edges in the second phase of wear is reflected in the increase in the grinding force component (in contrast to the shaping of surface roughness). While analyzing the course of surface roughness changes during the considered durability period, no significant changes in the $R a$ and $R z$ parameters were observed (fig. 6). Grinding wheels with monocrystalline corundum grain, in contrast to grinding wheels made of sintered corundum SG, do not have the possibility to obtain micro-edges as a result of the micrograins (components of SG grains) chipping.

\section{Conclusions}

Based on the results of the conducted tests, it can be stated that the grinding wheel with vitrified bond VE01 with assumed dressing and grinding parameters shows two areas dependent on the mechanism of wear in the durability period. The first area includes the wear of abrasive grains by reducing their sharpness (greater increase in the tangential component of the grinding force). In the second area, chipping of abrasive grains results in a radial wear of the grinding wheel, which was measured using an contact inductive sensor with a cylindrical tip, in order to add upGWAS profiles.

Grinding wheel wear has a strong effect on the grinding force components - both normal and tangential. The change of wear mechanism is noticeable by the change of force components gainduring the grinding wheel lifespan period.

Grinding wheel wear did not show significant influence on surface roughness parameters $R a$ and $R z$ after grinding.

The presented tests confirmed the possibility of using the grinding force components as an indirect method of assessing wear of grinding wheels with monocrystalline corundum grain.

Research co-financed under the project entitled "Grinding wheels for high-efficiency grinding with the use of new generation glass-ceramic binders" within the framework of the WROP for the years 2014-2020, Measure 1.2 Strengthening the innovative potential of Wielkopolska enterprises, option 1. Projects related to conducting $R \& D$ works.

\section{REFERENCES}

1. Jackson M.J., Mills B. "Microscale wear of vitrified abrasive materials". Journal of Materials Science. 39, 6 (2004): pp. 2131-2143.

2. Jackson M.J., Mills B., Hitchiner M.P. "Controlled wear of vitrified abrasive materials for precision grinding applications". Sadhana. 28, 5 (2003): pp. 897-914.

3. Toenshoff H.K., Denkena B. "Basics of Cutting and Abrasive Processes". Berlin, Heidelberg: Springer, 2013.

4. www.andre.com.pl (20.05.2018 r.).

5. Babiarz R., Żyłka Ł., Płodzień M. „Koncepcja budowy układu wysokociśnieniowego chłodzenia procesu szlifowania stopów lotniczych". Mechanik. 87, 8-9 CD (2014): pp. 4-7.

6. Kieraś S., Nadolny K., Wójcik R. „Aktualny stan wiedzy i techniki w zakresie chłodzenia i smarowania strefy obróbki w procesach szlifowania". Mechanik. 88, nr 8-9 CD1 (2015): pp. 204-211.

Translation of scientific articles, their computer composition and publishing them on the website www.mechanik.media.pl by original articles in Polish is a task financed from the funds of the Ministry of Science and Higher Education designated for dissemination of science.

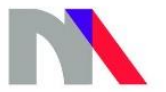

Ministry of Science and Higher Education Republic of Poland 